\title{
Internal Control, Social Responsibility and Corporate Financial Performance - Research based on Listed Food and Beverage Company in China
}

\author{
Miao Qin \\ School of management, Wuhan University of Technology, Wuhan 430000, China. \\ 305130534@qq.com
}

Keywords: Internal Control; Social Responsibility; Corporate Financial Performance; Sustainable Development.

\begin{abstract}
Since the release of "The 12th Five-Year Plan of Food Industry" in 2018, food safety problems have aroused public concern. From the point of view of improving financial performance, this paper analyzes the impact of internal control and social responsibility on financial performance of food and beverage listed companies in Shanghai and Shenzhen stock markets from 2012 to 2016.It is found that: there is a significant positive correlation between internal control and financial performance, social responsibility and financial performance have a positive correlation; internal control and social responsibility jointly promote the operation of the company. Therefore, the food and beverage industry should embed the scientific and standardized internal control system into the enterprise management and management process, at the same time, take on social responsibility at a higher level and in a wider scope, promote the scientific and healthy development of the enterprise, and achieve the established goal. The conclusion provides reference for the sustainable development of enterprises under the "New normal state" of the economy.
\end{abstract}

\section{Introduction}

In recent years, with the rapid development of economy, food safety problems are constantly emerging: from the exposure of "Melamine milk powder" of Sanlu in 2008, whole network report of "illegal cooking oil" event in 2010, smuggling "zombie meat" flowing into dining-table to the unlicensed business activity and inferior hygiene condition of "Eleme" stores exposed in the March 15th Party, the social problems caused by the food and beverage industry are worrying. This phenomenon stems from the unreasonable internal control model of the enterprise and its weak management foundation. On the other hand, it has a weak sense of corporate social responsibility and a lack of people-centered concept. Many enterprises have neglected to strengthen the quality of internal control, assume social responsibility and promote the internal link of business development, managers pursue economic development one-sidedly but neglect the importance of internal control and social responsibility, which impair the needs of various stakeholders of enterprises, as a result, the social trust of food and beverage industry is reduced, and it is difficult to maintain the sustainable development of enterprises. The purpose of this paper is to explore the relationship between internal control, social responsibility and financial performance through the empirical analysis of the relevant data of food and beverage industry, in order to improve the understanding of the triadic relation.

\section{Literature Review}

\subsection{The Relationship Between Internal Control and Financial Performance}

Cenglian Zhang, Jiawei Xie [1] established internal control evaluation system with 5 elements of internal control, which proved that internal control was positively related to financial performance; Chuan Zhang[2] et al. took real estate listed companies as research samples and adopted a questionnaire survey to obtain the conclusion that the effective implementation of the internal control system has a significant effect on improving company performance $\mathrm{Zi}$.Ye[3] takes the main board 
listed company of Shenzhen Stock Exchange as the research sample, taking the total value of internal control as independent variable, taking earnings per share, Tobin qand manipulation as dependent variables for regression analysis. It shows that internal control has no significant effect on financial performance.

\subsection{The Relationship Between Social Responsibility and Financial Performance}

A. P. Stanwick and D.S. Stanwick[4] used multiple regression analysis to analyze 115 listed companies and found that social responsibility and financial performance were positively correlated; Wenjing $\mathrm{Wu}[5]$ constructed two groups of mediating test models and found that the fulfillment of social responsibility has a partial mediating effect on company performance; Zhaoguo Zhang, Xiaocui Jin and Gengqin Li[6] pointed out that the impact of social responsibility on financial performance is lagging behind in time; Moore[7] pointed out that social responsibility had no obvious positive effect on financial performance and showed inverted U-type relationship.

To sum up, great achievements have been made in the research of the relationship among internal control, social responsibility and corporate performance in domestic and foreign academic circles. There is still no conclusion about the relationship among the three. Most scholars at home and abroad think that effective internal control helps to improve financial performance, but there are many different views on the impact of social responsibility on corporate performance. Scholars focus on the industry as a whole or electronic information, real estate industry, based on food, beverage industry analysis is less; scholars are mostly independent analysis of internal control, social responsibility and financial performance, there is little empirical analysis on the relationship between internal control and corporate performance from the perspective of the combination of internal control and social responsibility. Based on previous studies, this paper explores the relationship between internal control and financial performance in food and beverage industries, quantifies corporate social responsibility from the perspective of stakeholders, and specifically explores the relationship between each part and financial performance.

The main contributions of this paper: firstly, taking internal control, social responsibility as an independent variable, and financial performance as a dependent variable to build a model, deeper exploration of its relevance; secondly, putting the research perspective into the food and beverage industry, combined with the current hot issues, to make up for the lack of empirical analysis in the industry; thirdly, broaden the perspective of sustainable development of food and beverage enterprises, and providing a reference for the sustainable development of enterprises.

\section{Theoretical Analysis and Research Hypothesis}

\subsection{Internal Control and Financial Performance}

Internal control is not a system or method, but a dynamic economic activity associated with financial performance. The whole goal of internal control is to reduce or avoid the enterprise risk, realize the maximization of the enterprise value, and accord with the enterprise goal. Effective internal control can save the cost of internal control, improve the utilization of resources, establish good enterprise credit and improve the quality of capital market. Thereby, the following hypothesis has been put forward:

H1: There is a positive correlation between the quality of internal control and the financial performance

\subsection{Social Responsibility and Financial Performance}

The analysis of social responsibility in this paper is based on stakeholder theory, the core point is that good corporate social responsibility will improve the profitability of enterprises, which is very beneficial to shareholders, employees, customers, suppliers and so on. The theory emphasizes the interaction between the enterprise and the stakeholders of the society, and the positive performance of the social responsibility is beneficial to the sustainable development of the enterprise and the society. Thereby, the following hypothesis has been put forward: 
$\mathrm{H} 2$ : There is a positive correlation between corporate social responsibility and financial performance

\subsection{Internal Control, Social Responsibility and Financial Performance}

As a profit-making organization, the realization of financial objectives is the core of enterprise operation and production. Internal control ensures that the enterprise is responsible for the direct stakeholders such as shareholders, creditors, employees and so on from the financial point of view and realizes the narrow sense of social responsibility of the enterprise [8]. Internal control and social responsibility are interrelated, and the mutual effect of both sides can have a more obvious impact on financial performance. Thus, the hypothesis is proposed:

H3: The combination of social responsibility and internal control has a significant impact on financial performance

\section{Study Design}

\subsection{Sample Selection and Data Sources}

This sample of research comes from the data of listed companies in the food and beverage industry in Shanghai and Shenzhen in 2012-2016. During the sample selection process, the following processes were conducted: (1) excluding some listed companies that cannot obtain complete data, (2) excluding company ST and PT. Finally, effective observation samples are obtained. The internal control index is taken directly from DIB's internal control index released by DIB Enterprise Risk Management Technology Co., Ltd., with environmental indicators from Runling Global Social responsibility report. Net interest rates on total assets and other data are manually collated from the CSMAR. Data processing is done by Excel and Eviews software.

\subsection{Variable Design}

\subsubsection{Explained Variable}

The main indicators for measuring financial performance are Tobin $\mathrm{Q}$ and $\mathrm{ROA}$. Tobin $\mathrm{Q}=$ market value / total assets, mainly reflecting the company's ability to grow, focusing on measuring the long-term performance of the company; ROA is a short-term performance indicator that focuses on the status quo of business operations. Taking into account the immaturity of China's market regulation and the imperfection of the capital market, ROA is used to represent the financial performance of the company.

\subsubsection{Explanatory Variable}

(1) Internal control quality index. Hongming Chen and Xinting Liu [9] used the scoring method combined with expert opinions as weights to design the evaluation criteria for internal control, in order to avoid the influence of subjectivity. The internal control quality index of this paper comes from the "DIB China listed Company Internal Control Index" issued by DIB Company. It is based on internal control compliance, reporting, asset safety, and operation. Five strategic objectives of the degree of achievement of the design of the basic internal control index to reflect the level of internal control of food and beverage companies.

(2) Social responsibility related indicators. Yujun Miao and Dan Zhu [10] designed a variable definition table directly from studies that used the social contribution value of each share to represent corporate responsibility. In the first corporate social responsibility report of China's central enterprises in 2006, corporate social responsibility (CSR) is defined as that "Enterprises are responsible for owners, employees, customers, suppliers, communities and other stakeholders, as well as the natural environment, so as to achieve the coordinated development of enterprises and the sustainable development of economy and society.[11]" Based on the theory of stakeholders, in order to reflect corporate social responsibility in all aspects, it is expressed as a responsibility to consumers, employees, shareholders, the government, creditors, and the environment. 


\subsection{Controlled Variable}

Considering that the company's different scales and different asset-liability ratios will affect the company's performance, this paper introduces the company size (SIZE) and the asset-liability ratio (LEV) as control variables. The specific variables are explained in Table 1.

Table 1. Variable Definition

\begin{tabular}{|c|c|c|c|}
\hline Variable type & Variable name & $\begin{array}{l}\text { Variable } \\
\text { code }\end{array}$ & Variable interpretation \\
\hline $\begin{array}{l}\text { Explained } \\
\text { variable: }\end{array}$ & $\begin{array}{c}\text { Net interest rate on } \\
\text { total assets }\end{array}$ & ROA & $\begin{array}{l}\text { Net profit / (starting balance of total assets + closing balance of } \\
\text { total assets) }\end{array}$ \\
\hline \multirow{7}{*}{$\begin{array}{l}\text { Explanatory } \\
\text { variable }\end{array}$} & $\begin{array}{c}\text { Internal control } \\
\text { quality }\end{array}$ & ICQ & From the DIB internal control index. \\
\hline & Consumer & CUSCR & Operating cost rate \\
\hline & Employee & EMPCR & Cash/operating income paid to employees \\
\hline & Shareholder & EPS & Shareholders' net profit / total stock \\
\hline & Government & GOVCR & $\begin{array}{l}\text { (taxes and fees paid - return of taxes received)/operating } \\
\text { income }\end{array}$ \\
\hline & Creditor & CRECR & Net cash flows / liabilities arising from operating activities \\
\hline & Environment & ENVCR & $\begin{array}{l}\text { There is a quality management system certification of } 1 \text {, } \\
\text { otherwise it is } 0 \text {. The disclosure of environmental protection } \\
\text { investment is } 1 \text {, otherwise it is } 0\end{array}$ \\
\hline \multirow{2}{*}{$\begin{array}{l}\text { Controlled } \\
\text { variable }\end{array}$} & Asset-liability ratio & LEV & Total liabilities / total assets \\
\hline & Enterprise scale & SIZE & Natural logarithm of total assets \\
\hline
\end{tabular}

\section{Empirical Analysis}

\subsection{Descriptive Analysis}

Table 2 reports the descriptive results of the main variables. As can be seen from Table 2: From 2012 to 2016, the ROA of the selected sample companies is 0.06 , the maximum is 0.29 , the minimum is -0.26 , and the standard deviation is 0.07 , indicating that there is little difference in the total return on assets between food and beverage companies in China; the average ICQ value is 681.64, the maximum value is 920.20 , and the minimum value is 0.00 . This shows that although the industry has implemented effective internal control as a whole, the internal control performed by the companies is uneven; the maximum value of CUSCR is 1 and the minimum value is 0.25 , which shows that there is a certain gap between the business cost rate of the food and beverage industry; the maximum value of GOVCR is 0.33 , and the minimum value is -0.05 , which can be seen that the tax capacity and enthusiasm of the industry are quite different; the standard deviation of EmpCR is 0.05, and the standard deviation of cash expenditure for employees is 0.05 , which shows that the employee expenditure in the industry is roughly equal; the maximum value of EPS is 5.70, the minimum value is -1.47 , and the standard deviation is 1.06 , which indicates that the profit level of the food and beverage industry is high. The CRECR average is 0.29 , indicating that the industry is generally weak in solvency. 
Table 2. Descriptive Statistical Analysis

\begin{tabular}{|c|c|c|c|c|}
\hline Variable & Mean Value & Max & Min & Standard Deviation \\
\hline ROA & 0.06 & 0.29 & -0.26 & 0.07 \\
\hline ICQ & 681.64 & 920.2 & 0 & 99.02 \\
\hline CUSCR & 0.64 & 1 & 0.25 & 0.19 \\
\hline GOVCR & 0.14 & 0.33 & -0.05 & 0.11 \\
\hline EMPCR & 0.11 & 0.22 & 0.02 & 0.05 \\
\hline EPS & 0.78 & 5.7 & -1.47 & 1.06 \\
\hline CRECR & 0.29 & 1.11 & -0.31 & 0.3 \\
\hline ENVCR & 0.82 & 2 & 0 & 0.79 \\
\hline LEV & 0.35 & 0.78 & 0.06 & 0.16 \\
\hline SIZE & 22.68 & 24.85 & 20.83 & 1.06 \\
\hline
\end{tabular}

\subsection{Correlation Analysis}

In this paper, the correlation of various variables of the Sample Firms is tested. Table 3 gives the results of the Pearson correlation analysis of the variables in the test model.

From the table, in addition to asset liability ratio (LEV) and enterprise scale (SIZE), internal quality control (ICQ) and the net interest rate of total assets (ROA) the correlation coefficient is between 0.3349 and two were significant at 5\% level, namely the high quality internal control can promote the enterprise's financial performance. Consumers (CUSCR) and employees (EMPCR) are negatively correlated with total assets net interest rate (ROA) at a significant level of 5\%. There is a positive correlation between government, shareholders, creditors, environment and ROA. The hypothesis is preliminarily verified. But the correlation coefficient can only analyze the correlation between variables, so this paper analyzes the influence of each variable on the net interest rate of total assets by panel regression analysis.

Table 3. Pearson Correlation Coefficient Table

\begin{tabular}{|c|c|c|c|c|c|c|c|c|c|c|}
\hline $\begin{array}{l}\text { Correlation } \\
\text { Probability }\end{array}$ & ROA & $\mathrm{ICQ}$ & CUSCR & GOVCR & EMPCR & EPS & CRECR & ENVCR & LEV & SIZE \\
\hline ROA & $\begin{array}{r}1.000000 \\
-\end{array}$ & & & & & & & & & \\
\hline ICQ & $\begin{array}{r}0.334940 \\
0.0003\end{array}$ & $\begin{array}{r}1.000000 \\
-\cdots\end{array}$ & & & & & & & & \\
\hline CUSCR & $\begin{array}{r}-0.469142 \\
0.0000\end{array}$ & $\begin{array}{r}-0.030862 \\
0.7433\end{array}$ & $\begin{array}{r}1.000000 \\
----\end{array}$ & & & & & & & \\
\hline GOVCR & $\begin{array}{r}0.479907 \\
0.0000\end{array}$ & $\begin{array}{r}-0.048906 \\
0.6037\end{array}$ & $\begin{array}{r}-0.877098 \\
0.0000\end{array}$ & $\begin{array}{r}1.000000 \\
----\end{array}$ & & & & & & \\
\hline EMPCR & $\begin{array}{r}-0.345006 \\
0.0002\end{array}$ & $\begin{array}{r}-0.197598 \\
0.0343\end{array}$ & $\begin{array}{r}-0.261399 \\
0.0048\end{array}$ & $\begin{array}{r}0.236000 \\
0.0111\end{array}$ & $\begin{array}{r}1.000000 \\
-\end{array}$ & & & & & \\
\hline EPS & $\begin{array}{r}0.827993 \\
0.0000\end{array}$ & $\begin{array}{r}0.328952 \\
0.0003\end{array}$ & $\begin{array}{r}-0.503608 \\
0.0000\end{array}$ & $\begin{array}{r}0.517549 \\
0.0000\end{array}$ & $\begin{array}{r}-0.352858 \\
0.0001\end{array}$ & $\begin{array}{r}1.000000 \\
----\end{array}$ & & & & \\
\hline CRECR & $\begin{array}{r}0.572617 \\
0.0000\end{array}$ & $\begin{array}{r}0.159974 \\
0.0877\end{array}$ & $\begin{array}{r}-0.336115 \\
0.0002\end{array}$ & $\begin{array}{r}0.393975 \\
0.0000\end{array}$ & $\begin{array}{r}-0.055278 \\
0.5574\end{array}$ & $\begin{array}{r}0.439919 \\
0.0000\end{array}$ & $\begin{array}{r}1.000000 \\
----\end{array}$ & & & \\
\hline ENVCR & $\begin{array}{r}0.093189 \\
0.3219\end{array}$ & $\begin{array}{r}0.109384 \\
0.2445\end{array}$ & $\begin{array}{r}0.042898 \\
0.6490\end{array}$ & $\begin{array}{r}0.015981 \\
0.8654\end{array}$ & $\begin{array}{r}-0.215778 \\
0.0206\end{array}$ & $\begin{array}{r}0.190175 \\
0.0418\end{array}$ & $\begin{array}{r}0.175007 \\
0.0614\end{array}$ & $\begin{array}{r}1.000000 \\
-\cdots--\end{array}$ & & \\
\hline LEV & $\begin{array}{r}-0.331036 \\
0.0003\end{array}$ & $\begin{array}{r}0.058069 \\
0.5376\end{array}$ & $\begin{array}{r}0.379143 \\
0.0000\end{array}$ & $\begin{array}{r}-0.468669 \\
0.0000\end{array}$ & $\begin{array}{r}-0.337139 \\
0.0002\end{array}$ & $\begin{array}{r}-0.187029 \\
0.0453\end{array}$ & $\begin{array}{r}-0.493257 \\
0.0000\end{array}$ & $\begin{array}{r}0.171125 \\
0.0675\end{array}$ & $\begin{array}{r}1.000000 \\
-\end{array}$ & \\
\hline SIZE & $\begin{array}{r}0.442618 \\
0.0000\end{array}$ & $\begin{array}{r}0.294009 \\
0.0014\end{array}$ & $\begin{array}{r}-0.179173 \\
0.0554\end{array}$ & $\begin{array}{r}0.179459 \\
0.0550\end{array}$ & $\begin{array}{r}-0.362079 \\
0.0001\end{array}$ & $\begin{array}{r}0.548659 \\
0.0000\end{array}$ & $\begin{array}{r}0.163603 \\
0.0806\end{array}$ & $\begin{array}{r}0.239931 \\
0.0098\end{array}$ & $\begin{array}{r}0.186616 \\
0.0458\end{array}$ & $\begin{array}{r}1.000000 \\
---\end{array}$ \\
\hline
\end{tabular}

Note: The top half of each row in the table represents the value of the correlation coefficient of the variable, and the bottom half represents the $\mathrm{P}$ value corresponding to the test.

\subsection{Regression Analysis}

\subsubsection{Regression Analysis of Internal Control and Financial Performance}

Using ROA as the dependent variable, ICQ as the independent variable, and LEV and SIZE as the control variables, the mixed model was used to establish the regression analysis model. The results are shown in Table 4 . The estimated regression equation obtained through analysis is: 


$$
\begin{aligned}
& R O A=0.0001 * I C Q-0.1836 * L E V+0.0010 * \text { SIZE } \\
& (2.4437) \quad(0.0000) \\
& R^{2}=0.2244 \quad \bar{R}^{2}=0.2244
\end{aligned}
$$

The goodness of fit of the estimated equation is 0.2244 , and the corrected goodness of fit is 0.2106 , which is in high fitting level in the actual data. It can be seen from the equation that the effect of internal control quality on financial performance is positive. After $\mathrm{T}$ test, the value of $\mathrm{P}$ is 0.0161 . It can be seen that under the significant level of 5\%, the internal control has a positive correlation with the financial performance, which validates the hypothesis of H1. The main goal of internal control is to ensure that enterprises achieve their strategic goals and improve the quality of internal control, which helps to reduce or even avoid corporate risk and improve financial performance.

Table 4. Regression Analysis of Internal Control and Financial Performance

\begin{tabular}{lrrrr}
\hline \hline \multicolumn{1}{c}{ Variable } & Coefficient & \multicolumn{1}{c}{ Std. Error } & t-Statistic & Prob. \\
\hline \hline \multicolumn{1}{c}{ ICQ? } & 0.000160 & $6.56 \mathrm{E}-05$ & 2.443652 & 0.0161 \\
LEV? & -0.183637 & 0.039619 & -4.635092 & 0.0000 \\
SIZE? & 0.000950 & 0.002084 & 0.455962 & 0.6493 \\
\hline \hline & 0.224448 & Mean dependent var & 0.064773 \\
R-squared & 0.210598 & S.D. dependent var & 0.074688 \\
Adjusted R-squared & 0.066359 & Akaike info criterion & -2.561732 \\
S.E. of regression & 0.493195 & Schwarz criterion & -2.490125 \\
Sum squared resid & 150.2996 & Hannan-Quinn criter. & -2.532667 \\
Log likelihood & 0.554778 & & & \\
Durbin-Watson stat & & & & \\
\hline \hline
\end{tabular}

\subsubsection{Regression Analysis of Social Responsibility and Financial Performance}

Taking ROA as the dependent variable, taking EPS, EMPCR, GOVCR, CUSCR, ENVCR and CRECR as independent variables, LEV and SIZE as control variables, we get regression analysis, and the results are shown in Table 5. After analyzing the i fitted regression equation is:

$$
\begin{aligned}
& R O A=0.04 * E P S-0.29 * E M P C R-0.03 * G O V C R-0.05 * C U S C R-0.01 * E N V C R \\
& \begin{array}{llll}
(7.79) \quad(-3.22) \quad(-0.48) \quad(-1.29) \quad(-1.58)
\end{array} \\
& +0.05 * C R E C R-0.07 * L E V+0.01 * S I Z E \\
& \text { (3.52) (-2.45) (2.90) } \\
& R^{2}=0.7755 \quad \bar{R}^{2}=0.7608
\end{aligned}
$$

The goodness of fit of this equation is 0.7755 , and the goodness of fit after correction is 0.7608 , which is close to 1 , and the degree of fit is ideal. It is observed from the equation that shareholders and creditors have a positive effect on the net interest rate of the total assets. The $\mathrm{P}$ value of these two variables after $\mathrm{T}$ test is 0 and 0.0006 , which reflects that under the level of 5\%, social responsibility for shareholders and creditors is beneficial to improve corporate performance. The establishment of a social credit system, the maintenance of creditors' right to claim and the dividend distribution of shareholders will help improve business conditions, improve financial performance and achieve sustainable development; the effect of government, consumers, environment and employees on the net interest rate of assets is negative, however, the $\mathrm{T}$ test results show that the $\mathrm{P}$ values of the three variables are $0.6336,0.2007$ and 0.1168 , respectively, under the 5\% significant level, the three factors of government, consumers and environment have no obvious influence on the total assets net interest rate in the short run; at a significant level of 5\%, employees' negative impact on net asset interest rate is significant, which reflects that excessive employee burden will increase business expenses, increase cost and reduce business performance. Food and beverage companies should find a balance between financial performance and employee compensation and benefits. It is assumed that $\mathrm{H} 2$ is 
verified, that is, there is a positive correlation between corporate social responsibility and financial performance.

Table 5. Regression Analysis of Social Responsibility and Financial Performance

\begin{tabular}{crrrr}
\hline \hline Variable & Coefficient & Std. Error & t-Statistic & Prob. \\
\hline \hline EPS? & 0.040631 & 0.005217 & 7.787576 & 0.0000 \\
EMPCR? & -0.293167 & 0.090919 & -3.224497 & 0.0017 \\
GOVCR? & -0.031601 & 0.066102 & -0.478068 & 0.6336 \\
CUSCR? & -0.047612 & 0.036978 & -1.287597 & 0.2007 \\
ENVCR? & -0.007410 & 0.004686 & -1.581232 & 0.1168 \\
CRECR? & 0.053090 & 0.015078 & 3.520921 & 0.0006 \\
LEV? & -0.074952 & 0.030542 & -2.454018 & 0.0157 \\
SIZE? & 0.005150 & 0.001777 & 2.897718 & 0.0046 \\
\hline \hline & 0.775524 & Mean dependent var & 0.064773 \\
R-squared & 0.760838 & S.D. dependent var & 0.074688 \\
Adjusted R-squared & 0.036526 & Akaike info criterion & -3.714580 \\
S.E. of regression & 0.142751 & Schwarzcriterion & -3.523628 \\
Sum squared resid & 221.5883 & Hannan-Quinn criter. & -3.637073 \\
Log likelihood & 1.116157 & & & \\
Durbin-Watson stat & & & & \\
\hline \hline
\end{tabular}

\subsubsection{Regression Analysis of Internal Control, Social Responsibility and Financial Performance}

In order to explore the impact of internal control and social responsibility on financial performance as a whole, ROA was used as the dependent variable, ICQ, EPS, EMPCR, GOVCR, CUSCR, ENVCR, and CREC were independent variables, and LEV and SIZE were used as control variables for regression analysis. The results of the regression are shown in Table 6 . The fitting results obtained from Table 6 are as follows:

$$
\begin{array}{r}
R O A=0.04 * E P S-0.31 * E M P C R-0.01 * G O V C R-0.05 * C U S C R-0.01 * E N V C R \\
\begin{array}{r}
(7.30) \quad(-3.42) \\
+6.32 * 10^{-5} * I C Q+0.05 * C R E C R-0.07 * L E V+0.003 * S I Z E
\end{array} \\
(1.67) \quad(3.36) \\
R^{2}=0.7813 \quad \bar{R}^{2}=0.7648
\end{array}
$$

The goodness of fit of the equation is 0.7812 , and the corrected goodness of fit is 0.7648 . Compared with the previous model, the degree of fit of the model is significantly higher. It can be seen that the internal control variables and social responsibility variables are studied together and the equation fits better. The effect of variable EPS on the dependent variable ROA is significant at $10 \%$ significant level, and the effect of CRECR on ROA is significant at the significant level of $5 \%$. The impact of employees on ROA is significant under the 5\% significant level, and social responsibility is the intermediary variable of internal control and financial performance. H3 is tenable.

Table 6. Regression Analysis of Internal Control, Social Responsibility and Financial Performance

\begin{tabular}{crrrr}
\hline \hline Variable & Coefficient & Std. Error & t-Statistic & Prob. \\
\hline \hline ICQ? & $6.32 E-05$ & $3.78 E-05$ & 1.670778 & 0.0977 \\
EPS? & 0.038709 & 0.005301 & 7.302846 & 0.0000 \\
EMPCR? & -0.310147 & 0.090738 & -3.418056 & 0.0009 \\
GOVCR? & -0.008890 & 0.066950 & -0.132785 & 0.8946 \\
CUSCR? & -0.045079 & 0.036703 & -1.228209 & 0.2221 \\
ENVCR? & -0.007333 & 0.004648 & -1.577790 & 0.1176 \\
CRECR? & 0.050547 & 0.015031 & 3.362863 & 0.0011 \\
LEV? & -0.075535 & 0.030292 & -2.493578 & 0.0142 \\
SIZE? & 0.003224 & O.002106 & 1.530972 & 0.1288 \\
\hline \hline & 0.781283 & Mean dependent var & 0.064773 \\
R-squared & 0.764777 & S.D. dependent var & 0.074688 \\
Adjusted R-squared & 0.036224 & Akaike info criterion & -3.723182 \\
S.E. of regression & 0.139088 & Schwarzcriterion & -3.508362 \\
Sum squared resid & 223.0830 & Hannan-Quinn criter. & -3.635988 \\
Log likelihood & 1.093177 & & & \\
Durbin-Watson stat & \multicolumn{5}{c}{}
\end{tabular}




\section{Conclusion and Inspiration}

Through the analysis of the internal control, social responsibility and financial performance of listed companies in food and beverage companies for 2012-2016, the following conclusions have been reached: The effectiveness of internal control of enterprises is positively related to the financial performance, and the improvement of internal control quality can effectively improve the performance level; there is a positive correlation between social responsibility and financial performance, and the performance of corporate social responsibility can also help to improve financial performance; at the same time, social responsibility and financial performance are indispensable to corporate performance, the combined effect of the two has a more significant impact on financial performance. From the conclusion, enterprises should conduct the following related work:

Firstly, Food and beverage enterprises should reasonably plan the construction of internal control. Establish a complete system of internal control and attach importance to the implementation and supervision of relevant systems. From quality self-inspection to system supervision, from direct control to indirect control; conduct pre-control, in-process control to ex post control, to ensure the quality of internal control. Timely, comprehensive internal control information disclosure, in order to timely deal with control defects, reduce business risks.

Secondly, food and beverage companies should actively assume social responsibility. As an intangible asset, social responsibility can improve the reputation of enterprises and maintain the positive image of enterprises. Actively assume responsibility for society, promote quantitative disclosure of social responsibility information, and use media to publicize corporate social responsibilities to generate positive impacts, win the trust of stakeholders, and ensure that corporate stakeholders can formulate or fulfill optimal corporate contracts. Improve transaction efficiency and promote sustainable development of the company.

Thirdly, food and beverage enterprises should combine internal control and social responsibility to run through financial performance. Effective internal control is the amulet of the stakeholders, while social responsibility is the internal motive to promote the construction of internal control. Lack of checks and balances between stakeholders can lead to increased agency costs and weakened internal control effectiveness. Without the support of high quality internal control, the fairness and efficiency pursued by social responsibility cannot be achieved [12]. Without the support of high quality internal control, the fairness and efficiency pursued by social responsibility cannot be achieved. Promote effective interaction and mutual promotion, integrating processes and methods of internal control into social responsibility systems, and embedding the sense of social responsibility into the practice of internal control management, so as to promote enterprises to create social wealth while maximizing their own interests.

\section{References}

[1]. Zenglian Zhang, Jiawei Xie. Empirical Research on Earnings Quality, Financial Performance and Internal Control[J]. Accounting and Control Review. Vol. ((2011) No.2, p. 163-174.

[2]. Chuan Zhang, Hongbo Shen, Xinbiao Gao. Effectiveness of Internal Control, Auditor Evaluation and Corporate Performance [J]. Audit Research (2009) No. 6, p.79-86.

[3]. Hao Ye. An empirical study of internal control and corporate performance - based on an internal audit perspective [D]. (Professional Master Thesis, Beijing Jiaotong University, China, 2011). p. 1-46.

[4]. Peter A. Stanwick, Sarah D. Stanwick. The Relationship Between Corporate Social Performance, and Organizational Size, Financial Performance, and Environmental Performance: An Empirical Examination[J]. Journal of business ethics. Vol.17(1988) No.2, p. 195-204. 
[5]. Wenjing Wu. Research on Internal Control Effectiveness, Social Responsibility and Corporate Performance: Empirical Evidence from Chinese Listed Companies in Manufacturing Industry[D]. Academic Master Thesis, Jilin University of Finance and Economics, China, (2015). p. 1-48.

[6]. Zhaoguo Zhang, Xiaocui Kuang, Gengqin Li. Empirical Study on the Intertemporal Effects of Corporate Social Responsibility and Financial Performance Interactions[J]. Accounting Research. (2013) No.8, p.32-39.

[7]. Moore G. Corporate social and financial performance: an investigation in the U.k.supermarket industry[J].Journal of Business Ethnics,2001,34(3): p.299.

[8]. Lina Ma. Research on the Relationship between Internal Control and Corporate Social Responsibility [J]. Economic Forum. (2010) No.4, p.160-162.

[9]. Hongming Chen, Xinting Liu. Empirical analysis of the relationship among internal control, social responsibility, and financial performance - Taking the pharmaceutical manufacturing industry as an example[J]. Journal of Changsha University of Science and Technology. Vol.32(2017) No.2, p. 97-101.

[10]. Yujun Miao, Dan Zhu. Internal Control, Financial Performance and Social Responsibility of Companies: An Empirical Study of Listed Companies from Information Transmission, Software, and Information Technology Services Industry [J]. Friends of Accounting. (2017) No.12, p. $50-56$.

[11]. Gang Cai. Empirical research on the disclosure of social responsibility information of listed companies in China[J]. Economic Management Press. (2015) No.5, p11-12.

[12]. Lijun Tian. Social responsibility, internal control and corporate performance [J]. Chinese Certified Public Accountant (2012) No. 12, p48-55. 